\title{
Corn Futures: \\ Consumer politics, health, and climate change
}

Jedediah Purdy
James Salzman

The price of grain is now directly tied to the price of oil. We used to have a grain economy and a fuel economy. But now they're beginning to fuse. ${ }^{1}$

The Mexicans have long been known as the Corn People, but that label perhaps provides a better fit for modern day Americans. The simple seeds of corn play a fundamental role unprecedented in the history of human agriculture. Corn now underpins two major sectors, arguably the two most important sectors, of our modern economy food supply and energy supply. How we choose to consume this seed has far-ranging consequences for pressing issues as far apart as climate change and diabetes, energy policy and immigration, tropical deforestation and food riots. ${ }^{2}$

Recent years have brought surging interest in both the food we eat and the energy we use. The growth of farmers' markets around the country, the decision of major retailers such as Walmart to sell organic produce, and the popularity of grocery chains such as Whole Foods all bear witness to the fact that Americans care more and more about where their food comes from and how it was grown. The recent popularity of compact fluorescent light bulbs, hybrid cars such as the Prius, and voluntary carbon offsets similarly demonstrates that individuals see a connection between their behavior and climate change, and care enough to do something about it. ${ }^{3}$

As these examples make clear, individuals' concerns about food and climate are increasingly reflected in the marketplace. For a large number of people, consumption choices can become explicitly political choices, expressing both our personal values and the type of society we wish to create. As the journalist, Michael Pollan, has claimed,

We get three votes a day, actually more, when we eat. If we cast some of those votes with full consciousness of what's involved, and try to make better choices - which might entail spending more money or going out of our way - then that will help create the food chain we want. ${ }^{4}$

\footnotetext{
* Associate Professor of Law, Duke University

** Samuel F. Mordecai Professor of Law and Nicholas Institute Professor of Environmental Policy, Duke University. The authors are grateful for the research assistance of Jill Falor and Erin Daly.

${ }^{1}$ Steven Mufson, Siphoning Off Corn to Fuel Our Cars, Washington Post, April 30, 2008 at A1 (quoting Lester Brown, President of Earth Policy Institute).

${ }^{2}$ The first part of this article is largely based on the writings of Michael Pollan, who has popularized the modern significance of corn.

${ }^{3}$ See generally, Michael Vandenbergh, The Carbon- Neutral Individual, 82 NYU L.Rev. 1673, (2007).

${ }^{4}$ Bonnie Azab Powell, Journalism professor Michael Pollan's new book on the U.S. food chain provides few soundbites - but much to chew on, UC Berkeley News, 4/11/06, available at http://www.berkeley.edu/news/media/releases/2006/04/11_pollan.shtml [hereinafter Powell].
} 
Perhaps surprisingly, corn sits at the juncture of the food and fuel sectors, as the feedstock for much of our processed food and the fuelstock for ethanol. If we are what we eat, then we're corn on legs. ${ }^{5}$ If we are what we drive, we're increasingly corn on wheels. ${ }^{6}$

The rise of corn has brought great benefits, but its large and growing costs have also become increasingly clear. In this article, we explore the unprecedented roles of corn in our economy, explain how law and policy have shaped these roles, uncover the environmental and social impacts of corn, and consider how to think of consumption in this context. If voting-by-buying is an increasingly relevant model of consumer engagement, can we envision consumers being presented with choices that address the social and environmental harms from our dependence on corn? More generally, how should we think about consumer engagement, both its limits and its potential, in the context of corn's remarkable impact on our world today? It is no exaggeration to say that our future is inextricably linked with our future consumption choices of corn.

\section{The rise of corn}

We all studied in grade school the gift of corn from the Indians to the pilgrims. Corn became a staple crop of the early settlers and pioneers moving out West. Since the end of World War II, thanks to petroleum-based fertilizers, pesticides, herbicides and ever-more sophisticated hybridization, corn farmers have enjoyed increasing yields. This is equally true, however, for all commodity grains over the last fifty years. The difference for corn lies in the halls of Congress.

Simplifying the history, prior to the Depression era, agricultural subsidies were

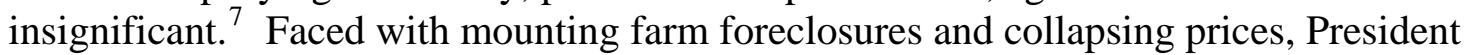
Roosevelt's Secretary of Agriculture, Henry Wallace, oversaw the creation of a loan system. In lean years when prices were low, farmers could take out government loans and stockpile corn until prices rose again, at which time the loan would be paid off. If the market did not rise, farmers could give their corn to the government as payment for the loan. The net result was a system that effectively smoothed out cyclical swings in supply and demand. In 1972, however, a series of unrelated events (grain sales to Russia coupled with a poor growing season) led to rapidly rising food prices. Eager to quell consumer unrest, Earl Butz, Secretary of Agriculture in the Nixon Administration, dramatically shifted policy. Instead of loans to be paid back when prices rose, farmers were provided price support payments. They essentially were paid to produce corn they could then sell on the open market. The current price support is twenty-eight cents per

\footnotetext{
${ }^{5}$ Powell, supra note XX.

${ }^{6}$ Literature on the impact of corn is filled with bad puns, including "The stalking of America," "Kernel knowledge," and "XX." See, e.g., Alex Chadwick and Mike Pesca, Overabundance of corn and its effect on the economy, available at <http://www.michaelpollan.com/press.php?id=16> [hereinafter NPR Interview]; Powell, supra note XX.

${ }^{7}$ This history of corn subsidies is drawn from Michael Pollan, Is corn making us fat?, NEW YORK TIMES, DEC. 8, 2003 [hereinafter Pollan NYT].
} 
bushel. ${ }^{8}$ As Pollan puts it, "We've been supporting agriculture since the Depression, but we've changed the way you do it - from essentially supporting the farmers to supporting the crop."9

As a result, farmers were paid for the production of corn, disconnected from market demand. The intended result was high production and low food prices, which is exactly what we have gotten until very recently. The consequences of this policy shift went far beyond corn-on-the-cob. With massive quantities of cheap corn available on the market, corn came to be viewed as a cheap, reliable feedstock for a dizzying number of uses. Cattle raising, for example, largely shifted from grazing to concentrated animal feed operations (CAFOs) because it became cheaper to buy corn than to use other feed or simply grow feed yourself. ${ }^{10}$ Developments in chemistry and food technology broke corn down into its constitutive compounds (sugars, proteins, stabilizers, etc.) and then reformed them for mass production of processed foods. ${ }^{11}$

In the Introduction, we claimed that Americans are largely corn on legs. A crazy claim? Consider that more than a quarter of the 45,000 items in a supermarket contain corn. $^{12}$ As measured by a mass spectrometer, the corn-derived carbon in a McDonald's Happy Meal comprises $100 \%$ of the carbon in a soda, $78 \%$ of the carbon in a milk shake, $56 \%$ in Chicken Nuggets, 52\% in a cheeseburger, and 23\% in French Fries, which you may have foolishly thought was all potato and cooking oil. ${ }^{13}$ The net result of all this can be seen as quite positive. The widespread use of cheap corn in processed foods has resulted in a huge drop in raw material costs of major food producers. ${ }^{14}$ Consumers have been the beneficiaries, enjoying much lower food prices for a dizzying range of products. Consider that in 1930, the average American family spent almost one-quarter of its disposable personal income on food. Today food costs account for less than onetenth. This has freed up a large percentage of a family's earnings to spend on other needs, such as education, housing and recreation. There is no question that increasingly low food prices have played a major role in the story of American prosperity. ${ }^{15}$

Turning to fuel, one finds a similar story. Corn used for ethanol has tripled since 2000 and now accounts for $95 \%$ of U.S. ethanol production. ${ }^{16}$ At first glance, using a renewable resource to substitute for nonrenewable oil looks quite attractive. Plants take carbon dioxide out of the air, so burning them should result in no additional carbon

\footnotetext{
${ }^{8}$ U.S. Department of Agriculture, Corn Briefing Room: Policy, available at

$<$ http://www.ers.usda.gov/briefing/Corn/policy.htm>.

${ }^{9}$ Powell, supra note XX.

${ }^{10}$ Powell, supra note XX.

${ }^{11}$ Michael Pollan, The Ominvore’s Dilemma: A Natural History of Four Meals 91 (2006)

[hereinafter Pollan].

${ }^{12}$ Powell, supra note XX.

${ }^{13}$ Powell, supra note XX.

${ }^{14}$ Pollan, supra note XX.

${ }^{15}$ U.S. Department of Agriculture, Food Expenditures by Families and Individuals as a Share of Disposable Personal Income, available at <http://www.ers.usda.gov/briefing/CPIFoodAndExpenditures/Data/table7.htm>.

${ }^{16}$ Frances Serra Whittelsy, Bio-Hope, Bio-Hype, SIERRA, Sept./Oct. 2007, at 50-51. [hereinafter Whittelsey].
} 
emissions, creating a boon for reducing greenhouse gas emissions. You are simply releasing the same carbon that the plant removed from the atmosphere. Indeed, several years ago major environmental groups called for even greater reliance on ethanol. ${ }^{17}$ Relying on corn grown in America to fuel American cars should decrease our dependence on foreign oil and its messy security entanglements. And, finally, this provides an important cash crop for rural America. The potential for ethanol in the overall energy mix looks promising. It has already become a mainstay of Brazil's energy mix. $^{18}$

\section{The Perils of Corn}

For both energy and food, the rise of corn at first seems a win-win, with a very bright upside. On closer examination, however, each story also presents a compelling dark side. The very cheapness of corn has made "supersizing" portions economical. The low cost of high-fructose corn syrup explains how convenience stores can turn a profit selling a half gallon of soda for 69 cents and how Coke could expand its standard soft drink bottle from the 8-ounce container of the 1970s to the 20 -ounce bottle today. ${ }^{19}$ The average American consumes over 40 pounds of high-fructose corn syrup every year; yet this compound was not even part of the human diet until $1975 .^{20}$ The low cost of corn as cattle-feed makes beef cheaper, allowing fast-food chains to supersize burgers and still sell them for less than ever before in inflation-adjusted terms. ${ }^{21}$ Perhaps the most serious consequences of this bounty have been the well-publicized obesity epidemic as well as problems of malnutrition and rickets among Americans otherwise found only in developing countries. ${ }^{22}$ Reliance on corn as cattle feed also raises animal welfare concerns, both over the cramped conditions in CAFOs and the ulcers caused by forcing a grass-feeding animal to subsist on corn. ${ }^{23}$

While transforming corn into ethanol should, other things equal, release fewer greenhouse gases than conventional fossil fuels, one is not simply burning a plant in a random field. Corn has to be grown, and that requires high petroleum-based inputs.

\footnotetext{
${ }^{17}$ See Danny Hakim, Beyond Gasoline: Filling Up With Ethanol, New York Times, September 10, 2005 ("David Friedman, a senior analyst at the Union of Concerned Scietists, an environmental group, said, 'ethanol has great potential to help the U.S. kick our oil habit, but that's 20 or 30 years away.'”).; see National Resources Defense Council,Growing Energy 1-10, December 2004, available at http://www.nrdc.org/air/energy/biofuels/biofuels.pdf (presenting the case for an aggressive push for biofuels.); see Danielle Murray, Ethanol’s Potential: Looking Beyond Corn, Earth Policy Institute, June 29, 2005, available at http://www.earth-policy.org/Updates/2005/Update49.htm ("With improved vehicle fuel economy and the use of more-efficient cellulosic feedstocks, biofuel has the potential to supply a substantial share of the world's automotive fuel.”)

${ }^{18}$ See, e.g, Andrew Downie, Brazil Fights Oil Prices With Alcohol, Christian SCIEnCE Monitor, Oct. 7, 2005.

${ }^{19}$ NPR Interview, supra note XX.

${ }^{20}$ Michael Pollan, Six Rules for Eating Wisely, Time, June 4, 2005. Available at

$<$ http://www.michaelpollan.com/article.php?id=77>.

${ }^{21}$ Pollan NYT, supra note XX.

${ }^{22}$ Powell, supra note XX.

${ }^{23}$ Powell, supra note XX.
} 
Every bushel of corn consumes roughly one-third to a half gallon of gasoline. ${ }^{24}$

Moreover, ethanol has to be synthesized. A 2005 study concluded that corn requires 29\% more fossil fuel than it replaces. So corn-based ethanol seems to be a loser in terms of greenhouse gases. $^{25}$ Nor is it truly cost-effective. Ethanol enjoys not only a 54 cent subsidy per gallon, but also a tariff of 54 cents per gallon on imported ethanol. ${ }^{26}$ The result is a net cost of $\$ 120$ for every barrel of oil saved by making ethanol. ${ }^{27}$

Crazy economics? Perhaps, but not crazy political economics. When John McCain ran for president in 2000, he declared that ethanol "is a product that would not exist if Congress didn't create an artificial market for it. No one would be willing to buy it ... Ethanol does nothing to reduce fuel consumption, nothing to increase our energy independence, nothing to improve air quality."28 Yet six years later, when campaigning in Iowa, the Straight-Talk Express featured a different message. McCain stated, "I support ethanol and I think it is a vital, a vital alternative energy source not only because of our dependency on foreign oil but its greenhouse gas reduction effects." 29 Perhaps it should come as no surprise that the 2007 Energy Bill mandates the use of 36 billion gallons of biofuel by 2022. ${ }^{30}$

This is a good time to be a farmer. The year 2007 recorded the largest corn harvest in history, up 24\% from 2006. ${ }^{31}$ Ethanol distilleries now consume a fifth of the country's corn crop. ${ }^{32}$ In the past three years, there have been record crops, but demand for foodstuffs, feed and fuel is growing, as well, driving up prices. Nor is this demand limited to the United States. As populous developing countries such as India and China get wealthier, their diets are shifting to greater consumption of meat. Producing 100 calories of beef, for instance, requires roughly 700 calories of grain, so the demand for animal feed should continue to grow well into the future. ${ }^{33}$

The perverse effects of corn's dominance, however, have proven more widespread than anyone anticipated, playing out in a number of dimensions. First, as the price of corn continues to go up, soy and wheat fields are converted to corn production. Soy and wheat supplies go down as demand stays constant or goes up, with the result of increasing costs for the foods dependent on these grains, such as meat, milk and eggs

\footnotetext{
${ }^{24}$ Michael Pollan, The Great Yellow Hope, NEw YoRK Times, May 24, 2006 [hereinafter Yellow Hope].

${ }^{25}$ Pimentel, D., and Tad Patzek, Ethanol Production Using Corn, Switchgrass, and Wood; Biodiesel Production Using Soybean and Sunflower. 14 NATURAL RESOURCES RESEARCH 65 (March, 2005).

${ }^{26}$ Yellow Hope, supra note XX.

${ }^{27}$ Yellow Hope, supra note XX.

${ }^{28}$ Corn Ethanol: The Great Boondoggle, A De Rigueur Scam to Appease the Hippies and the Heartland, available at <http://www.logicalscience.com/technology/bad/Ethanol.html>; Jon Birger, McCain's farm flip The senator has been a critic of ethanol. That doesn't play in Iowa. So the Straight Talk Express has taken a detour, FORTUNE, Oct. 312006.

${ }^{29} I d$. In response, Brown University professor Darrell West quipped, "Well, at least now we know he's serious about running for president." Ibid.

${ }^{30}$ Michael Grunwald, The Clean Energy Scam, Time, April 7, 2008, at 44. [hereinafter Grunwald]

${ }^{31}$ U.S. Dept. of Agriculture, 2007 Corn Crop a Record Breaker, USDA Reports, available at

<http://www.nass.usda.gov/Newsroom/2008/01_11_2008.asp>.

${ }^{32}$ Grunwald, supra note XX, at 42.

33 See Paul Roberts, The End of Food 209 (2007).
} 
(sometimes called "agflation"). Hence the incendiary claim by the UN special rapporteur on the right to food, that diverting arable from the production of crops to fuel is "a crime against humanity." 34

Second, as agricultural production responds to market signals and shifts toward high-profit crops, farmer remove land from the Conservation Reserve Program and other conservation programs. ${ }^{35}$ The government payments to retire agricultural land for ecosystem services such as erosion control and wildlife habitat are simply no longer high enough to compensate for market prices.

In a final knock-on effect, as corn production increases and the prices for soy and grain go up, international markets respond. In particular, Brazilian cattle pasture are converted to soy production (which is now commanding record prices), and cattlemen move into rainforest, accelerating tropical deforestation. ${ }^{36}$ As Brazilian ecologist, Sandro Menezes, has lamented, "The price of soybeans goes up and the forest comes down."”7 Overall, the conversion of rainforests, savannahs, grasslands for corn/sugarcane (ethanol) and palms/soybean (biodiesel) has led to a large destruction of carbon sinks and release of carbon stored in soils. Researchers estimate that this cascade has released 17 to 420 times more carbon than the annual savings from replacing fossil fuels. ${ }^{38}$

\section{Corn and the Politics of Consumption}

Corn is clearly becoming a salient political issue, but how should we think about the politics of consumption in this context? Can consumer decisions contribute to improving an environmentally and socially perverse corn economy? Thinking through this question provides not only a way of thinking more clearly about the future of corn; it also sheds light on the nature of consumption politics generally -- its potential and limits for the next generation of environmental challenges.

We first need to be clear on what it means to describe consumption as a political act. In broad terms, one can identify three distinct models of "Consumption as Politics." The first two are the most straightforward and well-developed, and are also the least likely to be effective in the context of corn. The third is both relatively complex and relatively nascent. Perhaps for both reasons, it has the greatest potential to affect both corn futures and other rising environmental challenges with some similar features, notably climate change.

\section{Consumption-channeling policy}

\footnotetext{
${ }^{34}$ Julian Borger, UN Chief Calls for Review of Biofuels Policy, THE GUARDIAN, April 5, 2008. Hence this analysis by Bloomberg's, "Land for soy oilseeds is increasingly being diverted to grow corn, reducing soy supply and driving up animal feed prices, according to the company.” Marianne Stigset, Ethanol Drives Up Food Commodity Prices, Datagro Says, Bloomberg.com, November 22, 2006.

${ }^{35}$ David Streitfeld, As Prices Rise, Farmers Spurn Conservation Program, New YoRK Times, April 9, 2008.

${ }^{36}$ Grunwald, supra note XX, at 42.

${ }^{37} \mathrm{Ibid}$.

${ }^{38}$ Joseph Fargione et al., Land Clearing and the Biofuel Carbon Debt, 319 SCIENCE 1235 (Feb. 7, 2008).
} 
The first model treats consumption not as a source of norms or law, but as an instrument of policy. In this top-down, centralized model, lawmaking frames individual consumption choices in a way that directs them in a socially desirable way. Government digs the channel through which consumption flows. Examples include "sin taxes" meant to discourage consumption of unhealthful products such as tobacco and alcohol; labeling requirements that encourage informed and health-conscious purchases; and default rules that take advantage of anchoring bias by automatically enrolling them in retirement programs unless they explicitly opt-out, rather than require them explicitly to opt in. As the examples suggest, these policies vary in their rationale and their instruments. As for rationale, sin taxes are paternalistic, raising the costs of unhealthful choices, while labeling requirements are compatible with market-libertarian principles in that they aim only at producing informed choices. As for instruments, default rules take advantage of cognitive bias, specifically the anchoring effect of an assigned starting point for a decision, while labeling requirements and taxes aim to affect the decision calculus in more straightforward ways.

However such policy is constructed, it is defined by involving consumption only as an instrument of centralized policymaking, usually formulated by a legislature or regulatory agency. The centralized authority establishes the goals and selects the policy instruments to pursue them; it so happens that these goals are achieved through the choices of consumers, decisions benevolently guided by government action. Although there may be some hope that the policies will set in motion a norm cascade or other change that is driven by consumption choices, rather than simply utilizing them, this is not the main intended effect of the policy.

\section{Conviction-expressing consumption}

The second model is very different. Call it conviction-expressing consumption, or just expressive consumption. The source of its goals is in the values of individual consumers. Consumers following this model try to make choices that are consistent with their core convictions and moral identities. These goals do not arise from government policy, as in the first, consumption-channeling model; nor are they part of a political strategy aimed at affecting such policy. Instead, they express the identities of the consumers. Consumers following this model may aim, for instance, to avoid purchases of meat raised in industrial conditions; products of exploited (e.g. "sweatshop," slave, or convict) labor; or food that is not produced locally.

Conviction-expressing consumption differs from consumption-channeling policy in both the source of its values (centralized political decisions versus individual conscience) and the standard of success (changing consumption patterns versus preserving the integrity of conscience). Each model also expresses a distinct strand of American political tradition. Consumption-channeling policy has its roots in the Progressive ambition for government: to manage a complex economy in keeping with 
“rational” social goals. ${ }^{39}$ While this tradition has recently been updated to reflect personal-liberty concerns, as in the "libertarian paternalism" of Cass Sunstein and Richard Thaler, the core ambition is that of welfarist Progressive regulators. ${ }^{40}$ By contrast, the conviction-expressing model goes back to the moral perfectionism of radical abolitionists influenced by William Lloyd Garrison, who sought to withdraw their consent and participation from a constitutional order that they saw as indelibly tainted by slavery. ${ }^{41}$ In modern consumption politics, it emerges from the writings of thinkers such as Wendell Berry, who argue that individuals should consume (economically and metabolically) in a way that minimizes their entanglement with an environmentally destructive agricultural economy. ${ }^{42}$

The line between expressive consumption and the third category, strategic consumption, can be ambiguous, but the core distinction lies in the standard of success. While both abolitionists and sustainability-oriented agrarians have hoped that their choices would influence the larger society, they have also counted their work done if their own choices are morally appropriate. The basic goal in this model is to protect the integrity of one's own conscience, though one hopes to influence others to do the same. In strategic consumption, the individual choice is an instrument of a political and publicrelations campaign to change policy: preserving one's own conscience is nice, but neither necessary nor sufficient for success, which comes with changing laws and institutional practices.

\section{Strategic consumption}

In strategic consumption, consumers make purchases in a manner intended to change the structure of the economy. As in conviction-expressing consumption, the consumer is a source of values; here, however, the standard of success is not just the bar of conscience, but the bar of politics - or of industry practice. Strategic consumption succeeds when individual choices contribute to a successful effort to change laws or institutional behavior.

Of course, expressive consumption choices may eoneatenate to result in similar effect by reducing economic reward to certain industry practices. What typically distinguishes strategic consumption is participation in some explicitly political movement or organization that links the consumption choices to a set of programmatic demands. This was the strategy, for instance, of the Rainforest Action Network's (RAN) campaign to induce Home Depot and other large home-improvement retailers to adopt sustainable

\footnotetext{
${ }^{39}$ See SAmuel P. Hays, Conservation And the Gospel Of Efficiency: The Progressive Conservation Movement, 1890-1920 (1999); Morton Keller, Regulating A New Economy: Public Policy AND ECONOMIC CHANGE IN AMERICA, 1900-1933 (1990).

${ }^{40}$ See Richard Thaler \& CASS R. Sunstein, Nudge: ImPROVIng DeCisions About Health, Wealth, AND HAPPINESS (2008).

${ }^{41}$ See Henry Mayer, All On Fire: William Lloyd Garrison And The Abolition Of Slavery (1998).

${ }^{42}$ See Wendell Berry, The Art Of The Common-Place: The Agrarian Essays Of Wendell Berry (NORMAN WIRZBA, ED.) (2002).
} 
sourcing policies for forestry products. ${ }^{43}$ The RAN presented itself as the representative of millions of conservation-minded consumers, and the prospect of a boycott, rather than any actual economic damage, convinced retailers to adopt sustainable-sourcing policies. Presumably a more complex economic calculus also informed the decision: such choices always depend on costs and benefits outside the ambit of strategic consumption, as well as those that strategic consumption choices can affect. Similar campaigns persuaded footwear and clothing manufacturers to adopt anti-sweatshop policies for their contractors in the late 1990s. ${ }^{44}$

The distinct advantage of strategic consumption as politics is twofold. First, the presence of a movement makes a consumption choice into an articulate "vote," which the targeted industry or government can understand, rather than a personal protest without a comprehending audience. Hence Pollan's claim that we have three votes a day, one at each meal. Second, strategic consumption can leverage a relatively small change in actual consumer behavior into a perceived threat to profit or legitimacy. Thus changed consumer behavior plus demands for specific changes in practices are potentially much more potent than changed consumer behavior alone.

\section{Consumption and the Corn Economy}

Consumption-channeling policy and expressive consumption both face serious limitations as approaches to the corn economy. While there are also reasons to doubt whether strategic consumption can be effective in this context, it has the greatest potential of the three models.

\section{Consumption-channeling policy and public choice}

The problem for consumption-channeling policy lies in its dependence on centralized political decisions as the source of values. As we set out earlier in this article, much of the perverse operation of the corn economy is a result of classic public-choice dynamics: agricultural interests' capture of legislative subsidies for both food-corn and energy-corn. Any consumption-channeling policy that aimed to reduce the prominence of corn in food or fuel would have to pass through the same legislative processes that have produced and sustained very substantial subsidies. This seems improbable, to say the least, without a major change in the incentives of legislators. A model of consumption politics that depends on government to generate its orienting values cannot pull itself up by the bootstraps to generate values opposite those the same government is presently pursuing. That sort of change depends on exogenous political activity.

\section{Expressive consumption: salience and relevance}

As noted earlier, while expressive consumption aims mainly at preserving the individual conscience, its marketplace impacts can eoneatenate to affect law or industry

\footnotetext{
${ }^{43}$ See Jedediah Purdy, Being America: Liberty, Commerce, And Violence In An AmericAn World 251-67 (2003).

${ }^{44}$ See id. at $149-66$.
} 
structure. Because we are concerned with policy, that is the possibility that interests us here. It is highly unlikely, however, that conscience-driven choices could be either widespread or effective enough for policy relevance unless they were linked to a campaign of strategic consumption.

The first reason this is true is the relevance of private choices. Most of the consumption decisions that drive the corn economy are not individual choices, but those of industrial actors in food and fuel production. This means that, unlike with a consumeroriented product such as tobacco, consumer decisions cannot simply "add up" to reducing or eliminating consumption of corn. To be effective, consumer decisions will have to feed back into corporate choices and, in all likelihood, the political decisions that set the context of corporate choice.

Pollan's image of consumption as voting ironically highlights the limits of expressive consumption as a source of change in the corn economy. The worth of a vote depends on the set of alternatives that the ballot offers and their relevance to the issues the consumer-voter might hope to affect. To envision the alternatives-deprived end of the spectrum, imagine a news report describing the re-election of an authoritarian dictator by $99.6 \%$ of the vote, on a ballot featuring him as the only candidate. That is not, to put it mildly, a potent vote. Some consumer choices relevant to the corn economy are of this character. In buying gasoline, for instance, one does not choose whether to include the ethanol additive in the purchase: that aspect of the ballot has been set by a prior political decision. In other cases, the consumer's ballot is skewed, as in a gerrymandered electoral system that favors an established party even when it receives less popular support than an insurgent alternative. Even if some consumers eschewed products containing corn, the economic effect of their choices would be substantially diluted by the legislative subsidies that structure industries’ sourcing decisions.

The second problem with expressive consumption is the likely salience of corn its prominence among the concerns of conscience that might inspire consumers to avoid it. Continuing with Pollan's electoral analogy, the efficacy of voting depends on voters' taking the trouble to be well informed about the choices presented on the ballot. Anyone but the most civic-minded knows the experience of marking the top of the ticket with great confidence, then descending into guesswork as the candidates for the school board come into view. With limited time and mental space, consumer choice tends to focus on a relatively small number of choices that make up, as it were, the cognitive top of the ticket. The issues most likely to acquire this salience are those to which some simple and vivid mental image attaches, such as children working in a workshop or a rainforest slashed and burnt; or those that come to embody a sharply perceived threat, such as alar, DDT, or asbestos. The need for salience does not favor an issue such as corn production, a highly complex system shaped by agricultural, economic, and political factors, which does not lend itself to a simple, morally charged mental image. 
Also disadvantageous is that corn lacks the poisonous associations of a fearsome shibboleth such as DDT: at worst, it is unhealthful, not toxic. ${ }^{45}$ Corn is, in short, a bad candidate for the top of the expressive consumer's cognitive ticket.

\section{Strategic consumption and the corn economy}

Strategic consumption is the most promising model for affecting the corn economy because it aims at either amplifying dissenting "votes," as with RAN campaigns, or changing the ballot by putting new political questions on the table. A strategic-consumption campaign, for instance, might announce a product boycott as expressing a demand to eliminate corn subsidies for food or fuel production, or both. Such a boycott might target, for instance, a restaurant chain using a large share of cornfed meat, or an oil company heavily engaged in the corn-ethanol industry; but the ultimate aim would be to create both the perception and the reality of widespread support for restructuring the corn economy, reaching all the way back to subsidies. Such a campaign would also be an appeal to consumers to treat the corn economy as an icon of environmental destruction, as rainforest clearing came to be in the 1980s and 1990s. In other words, it would be a dynamic engagement with the values of citizens and the interests of industries, as well as the government decisions that express and shape both of these.

A campaign of this sort might benefit from exogenous changes in the interests affecting political decisions. For instance, a growing clean-energy industry might demand that ethanol be stripped of its subsidies, and link its interest-based influence to the program of a strategic-consumption campaign.

The success of any strategic-consumption campaign would depend on unknowable factors: whether the campaign developed political salience in public minds, whether it identified visible and vulnerable boycott targets (or beneficiaries of supportive purchases), and whether it achieved alliances with interest-groups. Nonetheless, because it aims to affect not just individual choice, but the context of both individual and political choice, it is the alternative with the most potential to affect an issue with the characteristics of the corn economy: a complex system, without an obvious shibboleth, shaped by political decisions and industrial consumption, in which the existing ballot of consumer alternatives is less expansive than the chances that environmentally-oriented consumers would wish to bring about. It is impossible to forecast success for a multifarious and dynamic strategy; but it is equally impossible confidently to predict failure. The potential of the strategy is at least up to the nature of the problem.

\section{A Comparison: Corn and carbon}

\footnotetext{
${ }^{45}$ For a thoughtful exploration of the different aspects of the corn economy and the difficulty in labeling it simply good or bad, see the 2007 documentary, "King Corn," following the journey of two recent college graduates as they trace the paths of corn from a single acre they have planted in Iowa to its food and fuel markets. The film's website is at $<$ http://www.pbs.org/independentlens/kingcorn/>.
} 
Although space does not permit us to elaborate on the idea here, it is worth noting that corn shares many relevant features with that most urgent and au courant commodity, carbon. The foremost greenhouse gas contributing to climate change and the touchstone for proposed climate policies, carbon is a pervasive and frequently invisible part of nearly every sector of the economy - prominently including energy and agriculture. Invisibility, pervasiveness, and non-toxicity are all reasons to expect that it will be difficult for carbon to become a shibboleth of expressive consumption, just as it will likely be difficult for corn. Moreover, as with corn, many relevant carbon-consumption decisions are taken at the industrial level, by energy companies or manufacturers, rather than individuals, restricting the relevance of any expressive consumer agenda that did emerge. Finally, the carbon economy reflects political decisions to leave the harms of carbon emissions unpriced, that is, as externalities. Although this is technically different from the subsidies that structure the corn economy, it amounts to a subsidy relative to lower-carbon alternatives. This means that consumer choices will be pushing uphill unless attached to an explicit and politically effective agenda for structural reform of the price incentives surrounding carbon-consumption choices.

Carbon may be different from corn in one critical respect: the fact that Congress has embraced pro-carbon subsidies in the past might not be strong evidence that it will not take future steps to discourage carbon-emitting consumption. Climate change is an issue of sufficient perceived urgency that the political climate of tomorrow's debate may be relevantly different from that of the past. In other respect, however, corn and carbon are similar enough to yield a few parallel conclusions about the prospects of consumer politics to affect either issue. First, expect little systemic result from expressive choices, because the nature of the commodity (pervasive, often invisible, non-toxic) makes it unlikely to become highly salient and the pattern of consumption (institutional rather than individual, and with subsidies tilting the price structure) limits the possible relevance of consumer choices. Second, be skeptical of the prospects of centralized, top-down reforms to discourage harmful consumption - although changing political times may shift the ground enough to make such reform possible. Third, if results come from any quarter, it will likely be strategic consumption, which aims expressly to shift that political ground, and relies on consumer choices as instruments in a broader campaign.

\section{Conclusion}

The ideal of consumption-channeling policy is that a benign and rational government can shape the context of individual choice to benefit social welfare. The ideal of expressive consumption is that responsible individual choices can honor the demands of conscience and perhaps in the process contribute to a responsible economy. In the question of corn, consumption channeling is likely to fail because government decisions are neither rational nor benign, but the source of the corn economy's perverse features. Expressive consumption is also likely to fail, partly for reasons of salience, partly because those same government decisions limit the scope and possible efficacy of individual choice. 
Sometimes, to be able to choose responsibly, we must first change the context of our choices. To do so, in turn, we sometimes have to change the politics that shapes that context. The corn economy presents would-be reformers with just this kind of challenge. Although there is no guarantee of success, only the political mobilization of strategic consumption has much chance of finishing the job. 